\title{
KAJI CEPAT RESPONS MASYARAKAT PULAU PAGAI DI KEPULAUAN MENTAWAI TERHADAP GEMPABUMI SAMUDERA HINDIA 2 MARET 2016
}

\section{RAPID ASSESSMENT OF COMMUNITY RESPONSE TOWARDS THE 2 MARCH 2016 INDIAN OCEAN EARTHQUAKE IN PAGAI ISLAND MENTAWAI ARCHIPELAGO}

\author{
Novian Andri Akhirianto ${ }^{1}$
}

\begin{abstract}
ABSTRAK: Gempabumi Samudera Hindia berkekuatan 7,8 Skala Richter yang terjadi pada tanggal 2 Maret 2016 di sekitar $682 \mathrm{~km}$ barat daya Kepulauan Mentawai, Provinsi Sumatera Barat, menimbulkan berbagai reaksi spontan dari masyarakat yang terdampak. Respons masyarakat berbeda-beda terhadap gempabumi, peringatan dini, dan pemberitaan media. Kaji cepat sudah dilakukan dengan survei menggunakan kuesioner ke masyarakat Pulau Pagai secara sampling. Hasil kaji cepat respons masyarakat harapannya dapat digunakan sebagai bahan pembelajaran dan evaluasi bagi pihak-pihak terkait, dengan harapan untuk meminimalisir adanya korban akibat gempabumi dan tsunami.
\end{abstract}

Kata kunci: kaji cepat, respons masyarakat, gempabumi, sampling, Pulau Pagai.

ABSTRACT: Earthquake with the magnitude of 7.8 on the Richter Scale happened at about $682 \mathrm{~km}$ southwest of Mentawai Islands, West Sumatera Province on March 2, 2016. The spontaneous reaction of the affected people to the earthquake were varies. In particular the community response to the earthquake, early warning, and the media news were different. Rapid assessment survey using questionnaire was done to the Pagai Island communities. The results of these assessment are expected to be used as learning materials and evaluation for related parties, thereby to minimize the victims due to the earthquake and tsunami.

Keywords: rapid assessment, community response, earthquake, sampling, Pagai Island.

\section{PENDAHULUAN}

\subsection{Latar Belakang}

Pantai barat Pulau Sumatera merupakan salah satu kawasan yang memiliki aktivitas seismisitas yang tinggi. Tidak

1. PTRRB - BPPT, Gedung 820, GEOSTECH, PUSPIPTEK, Kota Tangerang Selatan. email: novian.andri@bppt.go.id terkecuali untuk kawasan segmen Mentawai - Sumatera Barat, kawasan ini merupakan kawasan yang menjadi langganan terjadinya gempabumi berkekuatan besar yang dapat mengakibatkan kerusakan. Sebut saja gempabumi tanggal 25 Oktober 2010 dan 2 Maret 2016 merupakan gempabumi signifikan terakhir yang terjadi di kawasan ini.

Pada tanggal 2 Maret 2016 terjadi gempabumi dengan Magnitude (M) 7.8 di Samudera Hindia. Goncangan gempa terasa 
di Sumatera Barat, terutama di Kepulauan Mentawai dan Kota dan Kabupaten di pesisir Sumatera Barat. Pada kejadian tersebut, Badan Meteorologi Klimatologi dan Geofisika (BMKG) mengeluarkan Peringatan Dini (PD) 1 level service 1, yaitu informasi gempabumi dengan M 8.3 di sebelah barat Kepulauan Mentawai yang berpotensi tsunami. PD 2 dimutakhirkan menjadi M 7.8 pada level service 2.

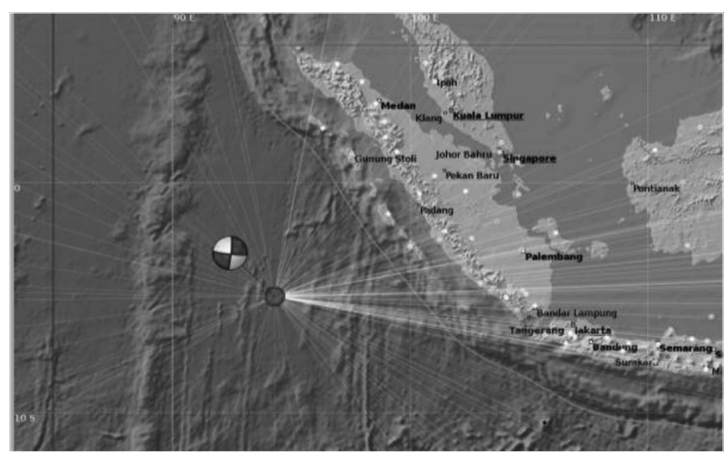

Gambar 1. Episentrum Gempabumi 2 Maret 2016

(Sumber: BMKG, 2016).

Respons masyarakat dari goncangan gempa yang terasa, peringatan resmi dan informasi dari media berbeda-beda, diantaranya kepanikan evakuasi dengan kendaraan, sehingga menimbulkan kemacetan dan kesimpangsiuran, substansi pemberitaan media lokal juga memicu kemungkinan kepanikan. Masyarakat di Kepulauan Mentawai dilaporkan melakukan evakuasi ke tempat yang lebih tinggi mengikuti informasi dari media (televisi).

Respons masyarakat dipengaruhi content media saat terjadi bencana dari rekan atau keluarga atau kemungkinan kepanikan timbul karena ada reaksi masyarakat sekitar yang panik, dan mungkin juga oleh arahan dari pemerintah setempat, baik secara langsung maupun tidak langsung.

Respons terhadap gempabumi merupakan pengalaman semua para pelaku, terutama di daerah terdampak dalam bereaksi terhadap gempabumi dan peringatan dini tsunami perlu untuk dikaji sebagai bahan evaluasi dan pembelajaran kedepan.

\subsection{Tujuan}

Tujuan dari kaji cepat ini yaitu untuk mempelajari respons masyarakat di Pulau Pagai, Kabupaten Kepulauan Mentawai pada kejadian Gempa 2 Maret 2016. Beberapa hal yang akan diidentifikasi antara lain:

- $\quad$ Apakah masyarakat menerima warning atau peringatan dini.

- Sumber informasi yang diterima terkait gempabumi dan peringatan dini.

- Respons masyakarat pada waktu terjadi gempabumi.

- Apa yang menjadi driving force dari respons masyarakat.

- Bagaimana masyarakat melakukan evakuasi dan alasan metode evakuasi yang dipilih.

\section{METODE PENELITIAN}

\subsection{Waktu dan Tempat Penelitian}

Penelitian ini dilakukan pada jangka waktu mulai tanggal 10 April 2016 sampai dengan 18 April 2016. Tempat penelitian berada di Pulau Pagai, Kabupaten Kepulauan Mentawai, Provinsi Sumatera Barat. Pemilihan Pulau Pagai sebagai tempat penelitian dilakuan secara purposive atau dengan sengaja, karena pada saat kejadian tsunami 25 Oktober 2010 daerah terdampak yang paling parah adalah Pulau Pagai, sehingga masyarakat Pulau Pagai mempunyai pengalaman yang lebih terhadap kejadian tsunami dibandingkan masyarakat Pulau Sipora dan Pulau Siberut.

\subsection{Pengambilan Data}

Penelitian ini dilakukan dengan melalui pengambilan data baik data primer maupun data sekunder. Metode yang digunakan untuk mendapatkan data primer melalui survei menggunakan kuesioner ke masyarakat pulau Pagai secara purposive sampling, yaitu pengambilan sampel berdasarkan "penilaian" (judgement) peneliti mengenai siapa saja yang pantas (memenuhi persyaratan) untuk 
dijadikan sampel. Purposive sampling dapat diartikan juga teknik pengambilan sampel sumber data dengan pertimbangan tertentu (Sugiyono, 2013).

\subsection{Analisis Data}

Analisis data yang digunakan dalam penelitian ini adalah menggunakan metode deskriptif dengan pendekatan kuantitatif. Metode deskriptif merupakan pemecahan masalah berdasarkan fakta-fakta, kemudian dianalisis dan diinterpretasikan. Pendekatan kuantitatif memberikan makna dari penafsiran angka yang tujuan akhirnya memberikan deskipsi statistik (Siregar, 2013).

\section{HASIL DAN PEMBAHASAN}

\subsection{Kondisi Geografis Pulau Pagai}

Pulau Pagai merupakan bagian dari wilayah Kabupaten Kepulauan Mentawai, Provinsi Sumatera Barat. Berdasarkan Undang-Undang Nomor 49 Tahun 2009, terbentuk Kabupaten Kepulauan Mentawai yang berasal dari sebagian wilayah Kabupaten Padang Pariaman yang terdiri atas 4 (empat) pulau besar yaitu Siberut, Sipora, Pagai Utara dan Pagai Selatan.

Pulau Pagai Utara dan Pagai Selatan dihubungkan oleh sebuah selat yang bernama Selat Sikakap, yang jaraknya sekitar 2 kilometer (km). Secara administratifPulau Pagai mempunyai batas-batas sebagai berikut:

- Sebelah Utara berbatasan dengan Selat Sipora.

- Sebelah Selatan berbatasan dengan Samudera Hindia.

- Sebelah Timur berbatasan dengan Selat Mentawai.

- Sebelah Barat berbatasan dengan Samudera Hindia.

Berdasarkan data dari Badan Pusat Statistik (BPS) Kabupaten Kepulauan Mentawai, Pulau Pagai memiliki luas daerah $1.521,61 \mathrm{~km}^{2}$. Pulau Pagai lebih luas dibandingkan Pulau Sipora yang hanya memiliki luas daerah $651,55 \mathrm{~km}^{2}$, akan tetapi lebih kecil bila dibandingkan dengan Pulau Siberut yang memiliki luas daerah mencapai $3.838,25 \mathrm{~km}^{2}$.

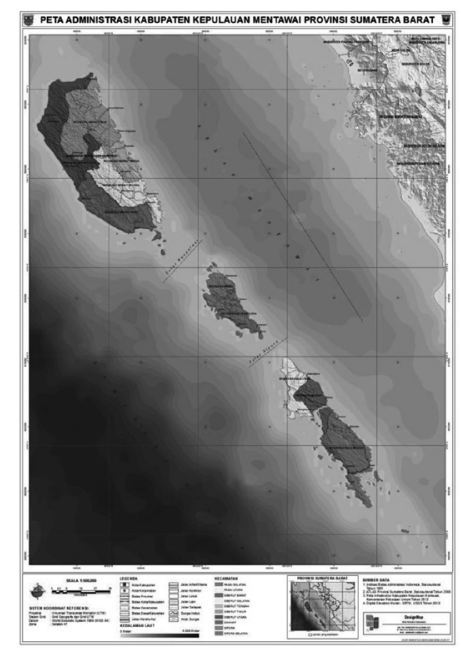

Gambar 2. Peta Administrasi Kabupaten Kepulauan Mentawai.

(Sumber: https://petatematikindo. files.wordpress.com).

Secara administratif Pulau Pagai terdiri dari 3 kecamatan dan 10 desa, secara detail dapat dilihat pada Tabel 1 berikut ini.

Tabel 1. Letak Geografis dan Jumlah Desa Tiap Kecamatan.

\begin{tabular}{|c|c|c|c|}
\hline No & Kecamatan & $\begin{array}{l}\text { Letak } \\
\text { Geografis }\end{array}$ & Desa \\
\hline \multirow{2}{*}{1} & \multirow{2}{*}{$\begin{array}{l}\text { Pagai } \\
\text { Selatan }\end{array}$} & $\begin{array}{r}2^{\circ} 49^{\prime} 04^{\prime \prime}- \\
3^{\circ} 21^{\prime} 00^{\prime \prime} \text { LS }\end{array}$ & \multirow{2}{*}{$\begin{array}{l}\text { - Bulasat } \\
\text { - Makalo } \\
\text { - Malakopa } \\
\text { - Sinaka }\end{array}$} \\
\hline & & $\begin{array}{c}100^{\circ} 07^{\prime} 01^{\prime \prime}- \\
100^{\circ} 32^{\prime} 00^{\prime \prime} \mathrm{BT}\end{array}$ & \\
\hline \multirow{2}{*}{2} & \multirow{2}{*}{ Sikakap } & $\begin{array}{l}\text { 2०37'12" - } \\
\text { 3॰55'04"LS }\end{array}$ & \multirow{2}{*}{$\begin{array}{l}\text { - Sikakap } \\
\text { - Matobe } \\
\text { - Taikako }\end{array}$} \\
\hline & & $\begin{array}{c}100^{\circ} 00^{\prime} 00^{\prime \prime}- \\
100^{\circ} 16^{\prime} 12^{\prime \prime} \mathrm{T}\end{array}$ & \\
\hline \multirow{2}{*}{3} & \multirow{2}{*}{ Pagai Utara } & $\begin{array}{l}2^{\circ} 30^{\prime} 00^{\prime \prime}- \\
3^{\circ} 51^{\prime} 36 " L S\end{array}$ & \multirow{2}{*}{$\begin{array}{l}\text { - Saumanganya } \\
\text { Betumonga } \\
\text { - Silabu }\end{array}$} \\
\hline & & $\begin{array}{c}99^{\circ} 57^{\prime} 00^{\prime \prime}- \\
100^{\circ} 09^{\prime} 36^{\prime \prime} \mathrm{BT}\end{array}$ & \\
\hline
\end{tabular}

Sumber: Kepulauan Mentawai Dalam Angka, (2014). 
Semua desa yang berada di Pulau Pagai memiliki garis pantai, adapun panjang garis pantai dari setiap desa dapat dilihat pada Tabel 2 berikut ini.

Tabel 2. Panjang Garis Pantai Tiap Desa.

\begin{tabular}{|c|c|c|c|}
\hline No. & Kecamatan & Desa & $\begin{array}{c}\text { Panjang } \\
(\mathrm{km})\end{array}$ \\
\hline \multirow{4}{*}{1} & \multirow{4}{*}{$\begin{array}{l}\text { Pagai } \\
\text { Selatan }\end{array}$} & Bulasat & 99,489 \\
\hline & & Makalo & 20,240 \\
\hline & & Malakopa & 86,516 \\
\hline & & Sinaka & 199,691 \\
\hline \multirow{3}{*}{2} & \multirow{3}{*}{ Sikakap } & Sikakap & 58,707 \\
\hline & & Matobe & 12,930 \\
\hline & & Taikako & 21,709 \\
\hline \multirow{3}{*}{3} & \multirow{3}{*}{ Pagai Utara } & Saumanganya & 43,274 \\
\hline & & Betumonga & 41,860 \\
\hline & & Silabu & 27,832 \\
\hline
\end{tabular}

Sumber. Kepulauan Mentawai Dalam Angka (2014).

\subsection{Kondisi Penduduk}

Jumlah penduduk terbanyak di Pulau Pagai adalah berada di Kecamatan Sikakap yang mencapai 10.312 jiwa, dengan jumlah kepala keluarga (KK) sebanyak $2.578 \mathrm{KK}$ dan tingkat kepadatan penduduk mencapai 37 jiwa/km2. Penduduk banyak terkonsentrasi di Kecamatan Sikakap disebabkan karena terdapat adanya pelabuhan untuk kapal yang menghubungkan Pulau Pagai dengan pulau atau daerah lain, seperti Padang, Bengkulu dan lain-lain.

Adapun data mengenai jumlah penduduk dan tingkat kepadatannya di Pulau Pagai dapat dilihat pada Tabel 3 berikut ini.

Tabel 3. Jumlah Kepadatan Penduduk Tahun 2013.

\begin{tabular}{|c|l|c|c|}
\hline No & Kecamatan & $\begin{array}{c}\text { Jumlah } \\
\text { Penduduk }\end{array}$ & $\begin{array}{c}\text { Kepadatan } \\
\text { (Jiwa/Km2) }\end{array}$ \\
\hline 1 & $\begin{array}{l}\text { Pagai } \\
\text { Selatan }\end{array}$ & 9.503 & 11 \\
\hline 2 & Sikakap & 10.312 & 37 \\
\hline 3 & Pagai Utara & 5.639 & 16 \\
\hline
\end{tabular}

Sumber. Kepulauan Mentawai Dalam Angka (2014).
Berdasarkan data statistik jumlah penduduk miskin di Pulau Pagai masih cukup banyak, yaitu mencapai lebih dari $50 \%$ dari jumlah penduduk di setiap kecamatan. Berikut adalah data penduduk miskin per kecamatan di Pulau Pagai.

Tabel 4. Jumlah Penduduk Miskin Tahun 2013.

\begin{tabular}{|c|l|c|}
\hline No. & Kecamatan & $\begin{array}{c}\text { Jumlah Keluarga Miskin } \\
\text { (KK) }\end{array}$ \\
\hline 1 & Pagai Selatan & 1.753 \\
\hline 2 & Sikakap & 1.926 \\
\hline 3 & Pagai Utara & 1.300 \\
\hline
\end{tabular}

Sumber. Kepulauan Mentawai Dalam Angka (2014).

Pulau Pagai dihuni oleh mayoritas masyarakat Suku Mentawai, yang dalam kacamata historio-antropos pada dasarnya adalah tipe masyarakat berburu dan meramu, dan tipe masyarakat berkebun (holtikultura) yang dilakukan oleh masyarakat yang tinggal di pedalaman jauh dari pantai. Sedangkan masyarakat yang bermukim di sekitar pantai, pekerjaan mereka adalah menangkap ikan, kerang atau kepiting, di sungai-sungai, rawa maupun di laut (dangkal).

Berdasarkan tipe-tipe mata pencaharian tersebut, untuk mempertahankan hidup mereka mengembangkan suatu pola kebudayaan yang berorientasi kepada pemanfaatan sumber daya yang tersedia di alam sekitar tempat bermukim sebagai modal dasar kehidupan, seperti untuk ekonomi, teknologi, pangan, perumahan, dan sosial. Secara substansial, masyarakat Pulau Pagai lebih memiliki orientasi nilai kehidupan yang selaras dengan alam dan tidak menguras alam untuk kepentingan hidup mereka. Kearifan lokal mereka adalah menjaga keseimbangan alam untuk kelangsungan hidup yang berkelanjutan, dari generasi ke generasi.

\subsection{Kronologi Kejadian Gempabumi}

Kronologi kejadian gempabumi di Samudera Hindia tanggal 2 Maret 2016 
Magnitude 7.8 SR sampai dengan proses diseminasi informasinya, diuraikan dalam bentuk time line seperti terlihat pada Tabel 5 di bawah ini.

Tabel 5. Time Line Gempabumi Samudera Hindia, 2 Maret 2016.

\begin{tabular}{|c|c|}
\hline Waktu (WIB) & Time Line \\
\hline $19: 51: 20$ & $\begin{array}{l}\text { Terjadi gempabumi yang terasa } \\
\text { langsung oleh observer di Stageof } \\
\text { PPI. }\end{array}$ \\
\hline $19: 51: 59$ & $\begin{array}{l}\text { Live sinyal dan Stasiun Status Blinking } \\
\text { (RGRI, MNAI, KOM, CHTO, BKNI, } \\
\text { BLSI, UGM, TRSI, PALK, SKJI, KUM, } \\
\text { PPSI, LWLI, CBJI, TSI, IGBI, KRJI, } \\
\text { PSI, SBSI, PPI, JMBI, TPRI, KASI, } \\
\text { PPBI, UBSI, DSRI, KLI, MKBI, LEM, } \\
\text { PMBI, KCSI, MDSI, SBM, MASI, LHM, } \\
\text { GSI, MNSI, KSM, IPM, TNGI, KKM, } \\
\text { UWJI, DGAR, SMRI, LASI, SBJI, } \\
\text { XMS). }\end{array}$ \\
\hline $19: 52: 12$ & $\begin{array}{l}\text { Mendapatkan laporan dari masyarakat } \\
\text { bahwa terjadi gempabumi yang } \\
\text { dirasakan di beberapa kota/ daerah. }\end{array}$ \\
\hline 19:53:00 & $\begin{array}{l}\text { Start Interaktif Tool Seiscomp3 } \\
\text { Automatic Analisa SeiscomP3 } \\
\text { berbunyi dan Analisa SeiscomP3 } \\
\text { secara manual. }\end{array}$ \\
\hline $19: 54: 05$ & $\begin{array}{l}\text { Mendapatkan parameter, OT = } \\
\text { 19:49:41 WIB 5.16 LS-94.05 BT, Mag } \\
\text { = 8.3 SR, Kedalaman: } 10 \mathrm{Km} \text { dan } \\
\text { dikirim ke ESDX. }\end{array}$ \\
\hline $19: 56: 10$ & $\begin{array}{l}\text { Mendapatkan info dari DVB dan } \\
\text { WRS kemudian pengiriman SMS } \\
\text { informasi parameter gempabumi } \\
\text { dari BMKG Pusat secara otomatis } \\
\text { dan mengeluarkan peringatan dini } \\
\text { tsunami. }\end{array}$ \\
\hline $19: 57: 00$ & $\begin{array}{l}\text { Memonitor keseluruhan sistem, } \\
\text { Alat processing lainnya dan media } \\
\text { komunikasi lainnya pembuatan berita } \\
\text { gempabumi dirasakan. }\end{array}$ \\
\hline $19: 57: 00$ & $\begin{array}{l}\text { Pengiriman Informasi dan } \\
\text { memberikan penjelasan gempabumi } \\
\text { dan peringatan dini tsunami melalui } \\
\text { media komunikasi lainnya yang } \\
\text { ada di Stageof PPI seperti telepon, } \\
\text { facebook, whatsapp, email, telegram. }\end{array}$ \\
\hline $20: 00: 10$ & $\begin{array}{l}\text { Memberikan informasi parameter } \\
\text { gempabumi dirasakan beserta } \\
\text { informasi daerah mana saja yang } \\
\text { merasakan ke PGN BMKG Pusat } \\
\text { melalui telepon. }\end{array}$ \\
\hline
\end{tabular}

\begin{tabular}{|c|c|}
\hline $20: 08: 00$ & $\begin{array}{l}\text { Mendapatkan Info pemutakhiran } \\
\text { peringatan dini tsunami di SUMBAR, } \\
\text { SUMUT, NAD, BENGKULU, } \\
\text { LAMPUNG dengan parameter, OT } \\
=19: 49: 47 \text { WIB } 4.92 \text { LS ; } 94.39 \\
\text { BT, Mag = } 7.8 \text { SR, Kedalaman: } 10 \\
\text { Km. Informasi tersebut didapat dan } \\
\text { disebarluaskan melalui DVB dan } \\
\text { WRS. }\end{array}$ \\
\hline 22:31:00 & $\begin{array}{l}\text { Mendapatkan info pemutakhiran } \\
\text { peringatan dini tsunami Mag }=7.8 \\
\text { SR, telah terdeteksi di Cocos Island } \\
(21: 15 \text { WIB) } 0.1 \text { meter dan Padang } \\
\text { (21:40 WIB) } 0.05 \text { meter didapat dan } \\
\text { disebarluaskan melalui DVB dan } \\
\text { WRS. }\end{array}$ \\
\hline 22:35:00 & $\begin{array}{l}\text { Mendapatkan info peringatan dini } \\
\text { tsunami yang disebabkan oleh gempa } \\
\text { Mag = 7.8 SR, tanggal } 2 \text { Maret } \\
2016 \text { 19:49:47 WIB dinyatakan telah } \\
\text { berakhir. Informasi tersebut didapat } \\
\text { dan disebarluaskan melalui DVB dan } \\
\text { WRS. }\end{array}$ \\
\hline 23:13:15 & $\begin{array}{l}\text { Mendapatkan info gempabumi } \\
\text { susulan dengan parameter OT = } \\
\text { 23:08:37 WIB } 3.75 \text { LS ; } 95.71 \mathrm{BT} \text {, } \\
\text { Mag = 5.2 SR, Kedalaman: } 198 \mathrm{Km} \text {. } \\
\text { Informasi tersebut didapat dan } \\
\text { disebarluaskan melalui DVB dan WRS }\end{array}$ \\
\hline
\end{tabular}

Sumber. BMKG (2016).

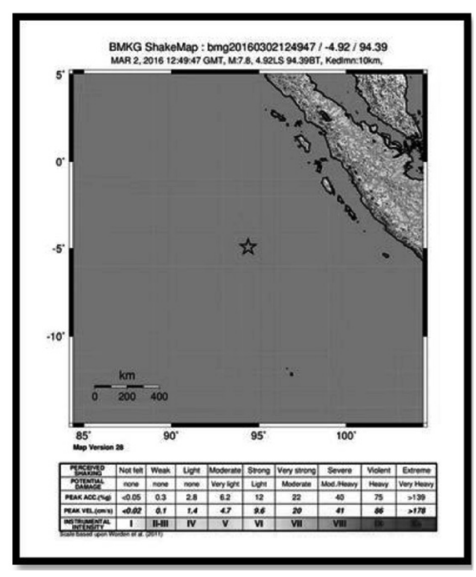

Gambar 3. Peta Goncangan Gempabumi Samudera Hindia 2 Maret 2016. (Sumber: Seismoteknik BMKG).

\subsection{Sebaran Responden}

Selama total 5 hari di lapangan untuk menyebar kuesioner diperoleh responden 
sebanyak 59 orang yang tersebar di beberapa desa dari 3 kecamatan yang ada di Pulau Pagai. Pemilihan target desa ini melalui beberapa pertimbangan seperti kepadatan penduduk, riwayat tsunami pada desa tersebut, serta kemungkinan adanya alat sistem peringatan dini tsunami yang dipasang di daerah tersebut. Adapun gambaran sebaran responden dapat dilihat pada Tabel 6 berikut ini.

Tabel 6. Sebaran Responden.

\begin{tabular}{|c|l|c|}
\hline No. & \multicolumn{1}{|c|}{ Kecamatan } & Jumlah Responden \\
\hline 1 & Pagai Selatan & 11 \\
\hline 2 & Sikakap & 23 \\
\hline 3 & Pagai Utara & 25 \\
\hline
\end{tabular}

Sumber. Hasil Analisis.

Berikut ini adalah jalur perjalanan dan sebaran responden yang dipetakan dari GPS ke dalam google earth.

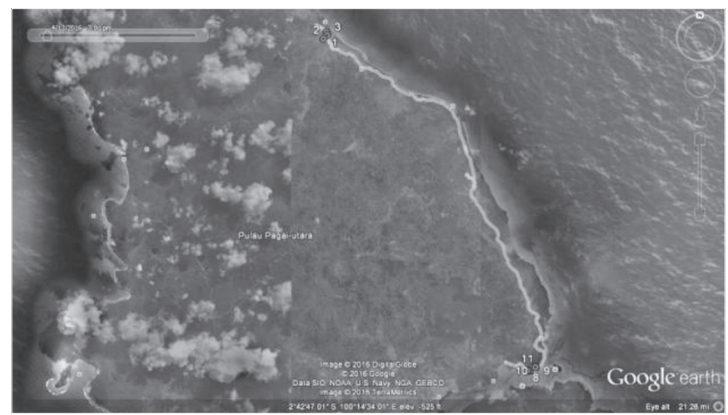

Gambar 4. Sebaran Responden dan Jalur Perjalanan ke-1.

(Sumber: Hasil Analisis).

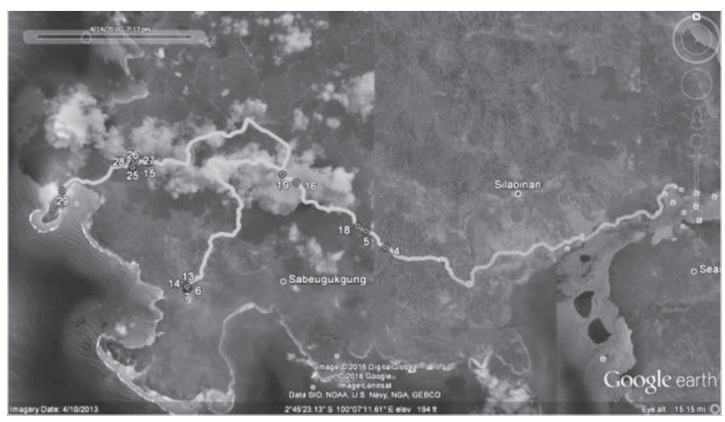

Gambar 5. Sebaran Responden dan Jalur Perjalanan ke-2.

(Sumber: Hasil Analisis).

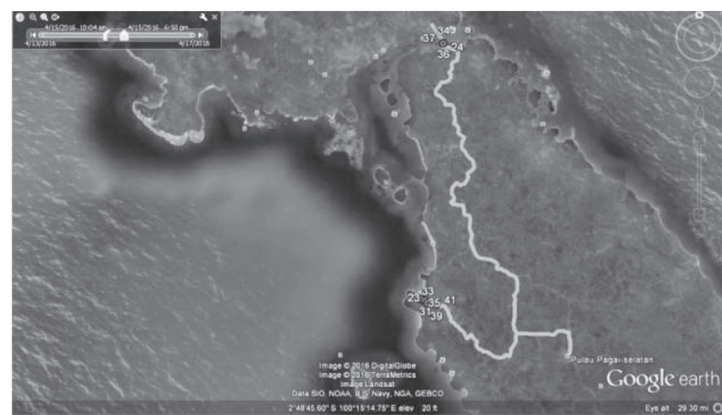

Gambar 6. Sebaran Responden dan Jalur Perjalanan ke-3.

(Sumber: Hasil Analisis).

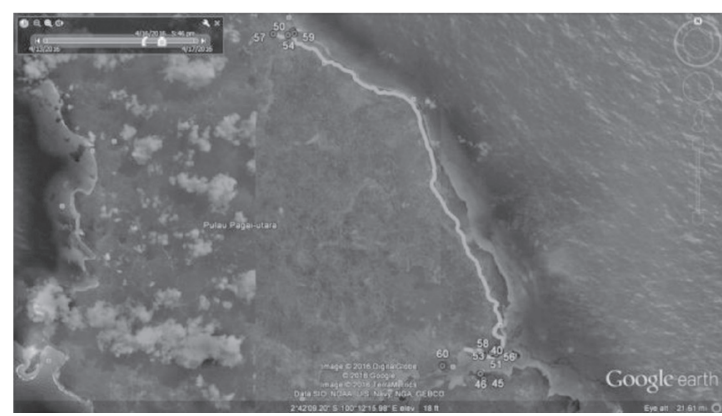

Gambar 7. Sebaran Responden dan Jalur Perjalanan ke-4.

(Sumber: Hasil Analisis).

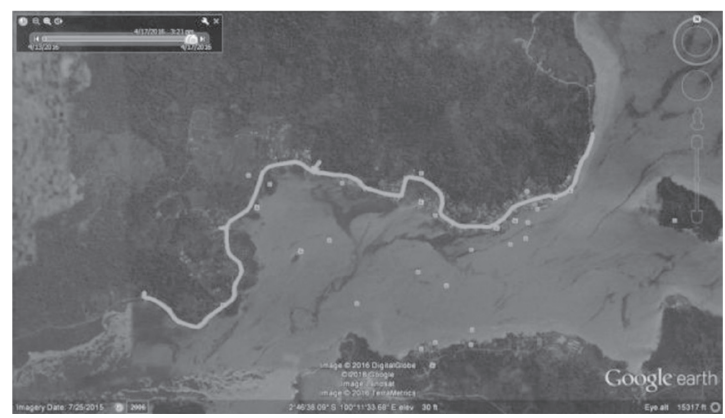

Gambar 8. Sebaran Responden dan Jalur Perjalanan ke-5.

(Sumber: Hasil Analisis).

\subsection{Analisis Deskriptif dengan Pendekatan Kuantitatif}

a. Gender Responden

Berdasarkan analisis data diperoleh hasil bahwa responden laki-laki 
lebih banyak dari pada responden perempuan, yaitu laki-laki sebanyak $54,2 \%$ dibanding perempuan sebanyak 45,8\%. Responden lakilaki lebih banyak dikarenakan lakilaki merupakan kepala keluarga sebagai pengambilan keputusan dalam keluarga ketika memutuskan untuk evakuasi atau tidak pada saat gempabumi terjadi. Data hasil analisis disajikan pada Tabel 7 berikut ini.

Tabel 7. Hasil Analisis Data Gender Responden.

\begin{tabular}{|l|c|c|c|}
\hline \multicolumn{1}{|c|}{ Gender } & Frequency & Percent & $\begin{array}{c}\text { Cumulative } \\
\text { Percent }\end{array}$ \\
\hline Laki-laki & 32 & 54,2 & 54,2 \\
\hline Perempuan & 27 & 45,8 & 100,0 \\
\hline Total & $\mathbf{5 9}$ & $\mathbf{1 0 0 , 0}$ & \\
\hline
\end{tabular}

Sumber. Hasil Analisis.

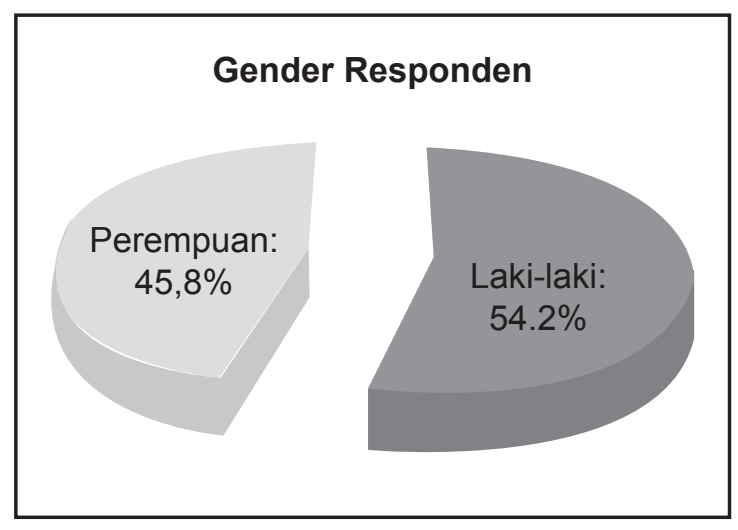

Gambar 9. Prosentase Gender Responden. (Sumber: Hasil Analisis).

\section{b. Umur Responden}

Berdasarkan analisis data diperoleh hasil bahwa responden terwakili oleh semua kelompok umur, dengan prosentase terbanyak ada di kelompok umur $31-40$ tahun $(35,6 \%)$. Dengan terwakilinya responden oleh semua kelompok umur diharapkan data yang diperoleh dapat lebih menggambarkan populasi terkait respons masyarakat terhadap gempabumi 2 Maret 2016 . Data hasil analisis disajikan pada Tabel 8 berikut ini.

Tabel 8. Hasil Analisis Data Umur Responden.

\begin{tabular}{|c|c|c|c|}
\hline Umur (tahun) & Frequency & Percent & $\begin{array}{c}\text { Cumulative } \\
\text { Percent }\end{array}$ \\
\hline $11-20$ & 4 & 6,8 & 6,8 \\
\hline $21-30$ & 7 & 11,9 & 18,6 \\
\hline $31-40$ & 21 & 35,6 & 54,2 \\
\hline $41-50$ & 11 & 18,6 & 72,9 \\
\hline $51-60$ & 14 & 23,7 & 96,6 \\
\hline $61-70$ & 2 & 3,4 & 100,0 \\
\hline Total & $\mathbf{5 9}$ & $\mathbf{1 0 0 , 0}$ & \\
\hline
\end{tabular}

Sumber. Hasil Analisis.

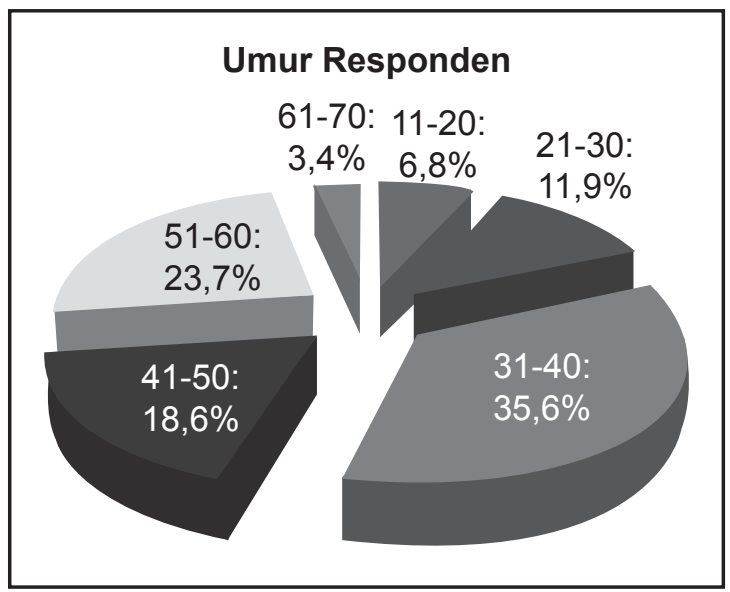

Gambar 10. Prosentase Umur Responden. (Sumber: Hasil Analisis).

\section{c. Tingkat Pendidikan Responden}

Berdasarkan analisis data diperoleh hasil bahwa responden terwakili oleh semua kelompok pendidikan, mulai dari responden yang tidak sekolah sampai dengan sarjana. Prosentase terbanyak adalah responden dengan pendidikan SMA atau sederajat $(30,5 \%)$, sedangkan responden terkecil adalah yang tidak sekolah dan D1, D2 atau D3 (5,1\%). Data hasil analisis disajikan pada Tabel 9 berikut ini. 
Tabel 9. Hasil Analisis Data Pendidikan Responden.

\begin{tabular}{|l|c|c|c|}
\hline Pendidikan & Frequency & Percent & $\begin{array}{c}\text { Cumulative } \\
\text { Percent }\end{array}$ \\
\hline Tidak sekolah & 3 & 5,1 & 5,1 \\
\hline SD/sederajat & 9 & 15,3 & 20,3 \\
\hline SMP/sederajat & 13 & 22,0 & 42,4 \\
\hline SMA/sederajat & 18 & 30,5 & 72,9 \\
\hline D1/D2/D3 & 3 & 5,1 & 78,0 \\
\hline S1/S2/S3 & 13 & 22,0 & 100,0 \\
\hline Total & $\mathbf{5 9}$ & $\mathbf{1 0 0 , 0}$ & \\
\hline
\end{tabular}

Sumber. Hasil Analisis.

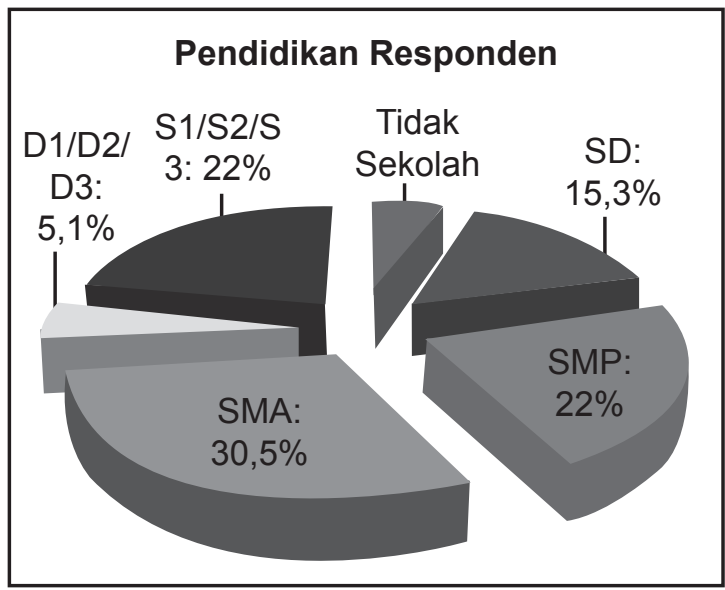

Gambar 11. Prosentase Pendidikan Responden. (Sumber: Hasil Analisis).

\section{Penerimaan Info Peringatan Dini}

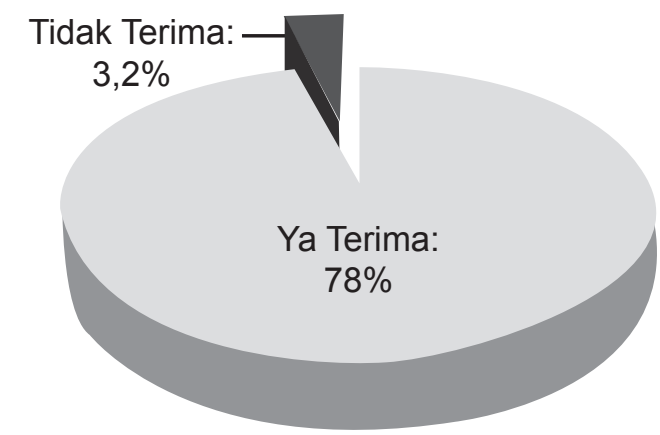

Gambar 12. Prosentase Penerimaan Informasi Peringatan Dini .

(Sumber: Hasil Analisis). d. Penerimaan Informasi Peringatan Dini

Berdasarkan analisis data diperoleh hasil bahwa responden sebagian besar menerima informasi peringatan dini gempabumi berpotensi tsunami. Prosentase responden yang menerima informasi peringatan dini sebesar $78 \%$, sedangkan sisanya $22 \%$ responden tidak menerima informasi tersebut.

Berdasarkan hasil wawancara dengan responden, sumber informasi peringatan dini yang terbanyak berasal dari:

- Televisi, yang berupa stop press, running text dan breaking news.

- Short Message Service (SMS) yang dikirim oleh BMKG kerjasama dengan dari Kominfo.

Responden yang tidak menerima informasi peringatan dini lebih banyak dikarenakan mereka tidak mempunyai handphone dan atau televisi. Peralatan sistem peringatan dini di Pulau Pagai pada saat survei dilakukan belum ada yang terpasang. Data hasil analisis disajikan pada Tabel 10 berikut ini.

Tabel 10. Hasil Analisis Data Penerimaan Informasi Peringatan Dini.

\begin{tabular}{|l|c|c|c|}
\hline Terima Info & Frequency & Percent & $\begin{array}{c}\text { Cumulative } \\
\text { Percent }\end{array}$ \\
\hline Ya & 46 & 78,0 & 78,0 \\
\hline Tidak & 13 & 22,0 & 100,0 \\
\hline \multicolumn{1}{r|}{ Total } & $\mathbf{5 9}$ & $\mathbf{1 0 0 , 0}$ & \\
\hline
\end{tabular}

Sumber. Hasil Analisis.

e. Sense Responden Terhadap Gempa Berdasarkan analisis data diperoleh hasil bahwa responden sebagian besar merasakan gempa yang terjadi pada tanggal 2 Maret 2016. Prosentase responden yang merasakan adanya gempa adalah sebesar $79,7 \%$, sedangkan sisanya 20,3\% tidak merasakan.

Berdasarkan hasil wawancara dengan 
responden yang merasakan adanya gempa sebagian besar mengatakan bahwa benda-benda ringan yang digantung bergoyang. Data hasil analisis disajikan pada Tabel 11 berikut ini.

Tabel 11. Hasil Analisis Data Sense Responden Terhadap Gempa.

\begin{tabular}{|r|c|c|c|}
\hline \multicolumn{1}{|c|}{$\begin{array}{c}\text { Sense } \\
\text { Gempa }\end{array}$} & Frequency & Percent & $\begin{array}{c}\text { Cumulative } \\
\text { Percent }\end{array}$ \\
\hline Ya Merasakan & 47 & 79,7 & 79,7 \\
\hline $\begin{array}{l}\text { Tidak } \\
\text { Merasakan }\end{array}$ & 12 & 20,3 & 100,0 \\
\hline Total & $\mathbf{5 9}$ & $\mathbf{1 0 0 , 0}$ & \\
\hline
\end{tabular}

Sumber. Hasil Analisis.

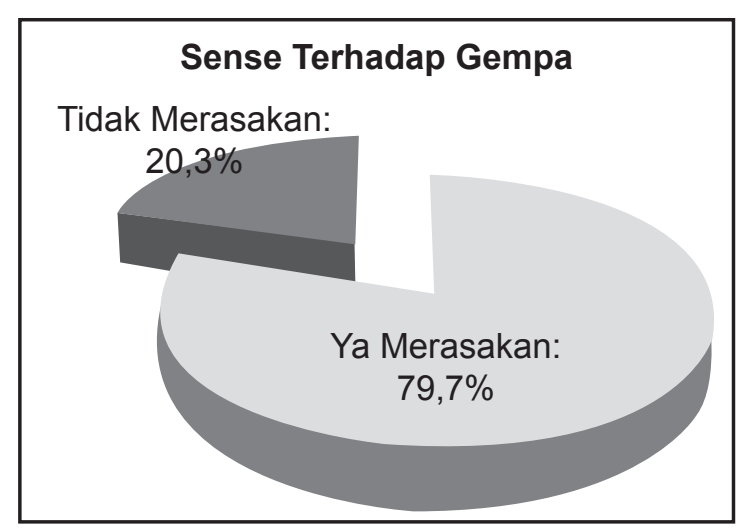

Gambar 13. Prosentase Sense Responden Terhadap Gempa.

(Sumber: Hasil Analisis).

\section{f. Respons Untuk Evakuasi}

Berdasarkan analisis data diperoleh hasil bahwa responden sebagian besar segera melakukan evakuasi setelah merasakan adanya gempa, dikarenakan mereka masih trauma dengan pengalaman kejadian tsunami pada tahun 2010. Adapula responden yang melakukan evakuasi tetapi tidak segera setelah gempabumi terjadi, dengan alasan menunggu perintah dari aparat pemerintah setempat. Sebagian lagi adalah responden yang tidak melakukan evakuasi sama sekali, dengan kebanyakan alasanya adalah karena gempabumi yang dirasakan lemah, serta air laut tidak mengalami surut. Data hasil analisis disajikan pada Tabel 12 berikut ini.

Tabel 12. Hasil Analisis Data Respon untuk Evakuasi.

\begin{tabular}{|l|c|c|c|}
\hline $\begin{array}{c}\text { Keputusan } \\
\text { Evakuasi }\end{array}$ & Frequency & Percent & $\begin{array}{c}\text { Cumulative } \\
\text { Percent }\end{array}$ \\
\hline Ya segera & 26 & 44,1 & 44,1 \\
\hline $\begin{array}{l}\text { Ya tapi tidak } \\
\text { segera }\end{array}$ & 12 & 20,3 & 64,4 \\
\hline Tidak evakuasi & 21 & 35,6 & 100,0 \\
\hline Total & $\mathbf{5 9}$ & $\mathbf{1 0 0 , 0}$ & \\
\hline
\end{tabular}

Sumber. Hasil Analisis.

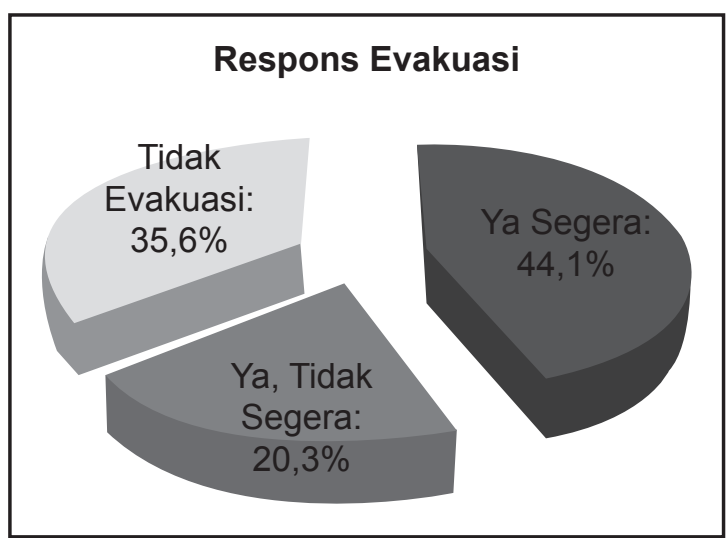

Gambar 14. Prosentase Respon Responden Untuk Evakuasi.

(Sumber: Hasil Analisis).

\section{g. Metode Evakuasi}

Berdasarkan analisis data diperoleh hasil bahwa responden sebagian besar melakukan evakuasi dengan cara berjalan kaki, hal tersebut karena jalur evakuasi relatif menanjak, sempit dan berada di perbukitan. Oleh karena itu, tidak banyak responden yang melakukan evakuasi dengan menggunakan kendaraan (sepeda motor). Tempat evakuasi sementara yang banyak dituju oleh responden adalah tanah lapang ataupun bangunan yang berada di dataran tinggi, seperti gereja, sekolah, dan lain-lain. 


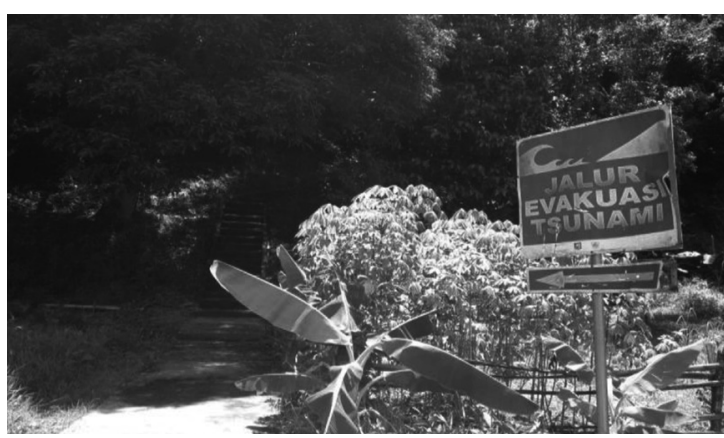

Gambar 15. Jalur Evakuasi di Kecamatan Sikakap.

(Sumber: Survei Lapangan, 2016).

Tabel 13. Hasil Analisis Data Metode Evakuasi.

\begin{tabular}{|l|c|c|c|}
\hline \multicolumn{1}{|c|}{$\begin{array}{c}\text { Metode } \\
\text { Evakuasi }\end{array}$} & Frequency & Percent & $\begin{array}{c}\text { Cumulative } \\
\text { Percent }\end{array}$ \\
\hline Berjalan kaki & 24 & 40,7 & 40,7 \\
\hline Berlari & 14 & 23,7 & 64,4 \\
\hline $\begin{array}{l}\text { Menggunakan } \\
\text { sepeda motor }\end{array}$ & 11 & 18,6 & 83,0 \\
\hline Lainnya & 1 & 1,7 & 84,7 \\
\hline $\begin{array}{l}\text { Tidak } \\
\text { menjawab }\end{array}$ & 9 & 15,3 & 100,0 \\
\hline \multicolumn{1}{|c|}{ Total } & $\mathbf{5 9}$ & $\mathbf{1 0 0 , 0}$ & \\
\hline
\end{tabular}

Sumber. Hasil Analisis.

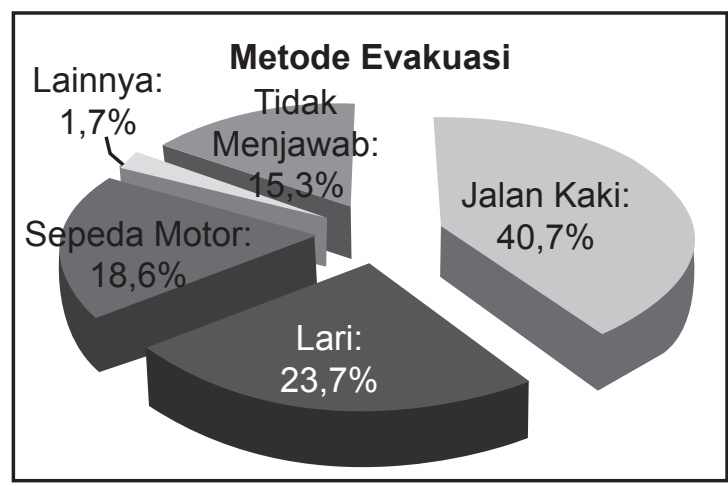

Gambar 16. Prosentase Metode Evakuasi. (Sumber: Hasil Analisis).

\section{KESIMPULAN}

Berdasarkan hasil kajian di atas, maka dapat disimpulkan beberapa hal sebagai berikut:

a. Masyarakat Pulau Pagai $78 \%$ menerima warning atau peringatan dini gempabumi berpotensi tsunami, sisanya $22 \%$ tidak menerima warning.

b. Sumber informasi peringatan dini yang terbanyak berasal dari:

- Televisi, yang berupa stop press, running text dan breaking news.

- Short Message Service (SMS) yang dikirim oleh BMKG kerjasama dengan dari Kominfo.

c. Respons masyarakat Pulau Pagai pada saat terjadi gempabumi $44,1 \%$ segera melakukan evakuasi, $20,3 \%$ melakukan evakuasi tetapi tidak segera setelah terjadi gempabumi, dan $35,6 \%$ tidak evakuasi sama sekali.

d. Driving force dari respons masyarakat yang evakuasi adalah karena merasakan gempa dan trauma akan pengalaman kejadian tsunami tahun 2010. Sedangkan driving force dari respons masyarakat yang tidak evakuasi adalah karena gempabumi yang dirasakan lemah dan air laut tidak mengalami surut.

e. Masyarakat Pulau Pagai terbanyak melakukan evakuasi dengan cara berjalan kaki, dengan prosentase sebesar 40,7\%. Alasan evakuasi dengan jalan kaki karena jalur evakuasi relatif menanjak, sempit dan berada di perbukitan.

\section{UCAPAN TERIMA KASIH}

Ucapan terima kasih disampaikan kepada rekan-rekan Tim Kaji Cepat Gempabumi Samudera Hindia 2 Maret 2016, 
yang sudah bekerjasama dengan baik. Direktur dan Kabag Program dan Anggaran PTRRB yang sudah memberikan ijin kepada penulis untuk melaksanakan kegiatan ini. Serta semua pihak sponsor yang telah mendanai kegiatan ini.

\section{DAFTAR PUSTAKA}

Badan Pusat Statistik Kabupaten Mentawai Kerjasama Badan Perencanaan Pembangunan Daerah Kabupaten Kepulauan Mentawai, 2014, Kepulauan Mentawai Dalam Angka, Mentawai.
https://id.wikipedia.org/wiki/Kabupaten Kepulauan_Mentawai, Diakses pada $2 \overline{4}$ November 2016.

https://petatematikindo.files.wordpress.com, Diakses pada 24 November 2016.

http://www.mentawai-travel.com/page/profilkondisi-geografi, Diakses pada 24 November 2016.

Siregar, S., 2013, Statistik Parametrik untuk Penelitian Kuantitatif, Jakarta, P.T. Bumi Aksara.

Sugiyono, 2013, Metode Penelitian Kuantitatif, Kualitatif dan R\&D, Bandung, C.V. Alfabeta. 